\title{
Death of two eminent members of the Movement
}

The ICRC learned with deep sadness of the death on 24 September 1988 of General Pietro Verri, President of the Florence Branch of the Italian Red Cross, and the death on 16 October 1988 of Mr. Soehanda Ijas, Co-Chairman of the Indonesian Red Cross.

General Verri, former Vice-Commander of the Arma dei Carabinieri, was an active supporter of the Red Cross and a tireless champion of international humanitarian law (IHL), a subject in which he was well versed. He was a member of the Italian delegation to the Diplomatic Conference which led, in 1977, to the adoption of the Protocols additional to the 1949 Geneva Conventions and as a profilic author and translator did much to promote the dissemination of IHL in his country. He drew his ability to do so from a flawless knowledge of the theoretical questions underlying the law of armed conflicts, coupled with a vast experience of the practical problems arising from the implementation of these rules. For several years he also acted as director of the courses set up by the Italian Red Cross to train instructors of humanitarian law and regularly taught the law of armed conflicts to members of the Air Force and Police Officer Academies.

$\mathrm{He}$ contributed substantially to the activities of the International Institute of Humanitarian Law in San Remo as a member since 1972 and as President, from 1980 to 1986, of its Academic Comittee on Military Courses.

General Verri's work in the field of IHL included close co-operation with the ICRC, which he recently authorized to publish a French version of his "Dizionario di diritto internazionale dei conflitti armati", a thorough and very practical guide to the major concepts encompassed by the two branches of international law known as jus ad bellum and jus in bello.

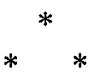


Mr. Soehanda Ijas, Secretary General of the Indonesian Red Cross from 1966 to 1986, contributed on a large scale to developing the National Society's work in his country and abroad. He was a member of the Commission on the Red Cross, Red Crescent and Peace and of the Working Group on the Revision of the Statutes of the Movement and of the ICRC/League Agreement. He was also a member of the Standing Commission of the Red Cross and Red Crescent from 1981 to 1986 .

The ICRC will honour the memory of these two faithful servants of the humanitarian cause. 